\title{
Preliminary phytochemical screening of wild edible fruits from Boda and Kolli hills
}

\author{
S. P. Anand ${ }^{*}$, S. Deborah \\ PG and Research Department of Botany, National College (Autonomous), Tiruchirappalli, Tamil Nadu, India
}

Received: 27.01 .2017

Accepted: 12.03 .2017

Published: 15.03.2017

*Address for Correspondence:

S. P. Anand, PG and Research Department of Botany, National College (Autonomous), Tiruchirappalli - 620001 , Tamil Nadu, India.

E-mail: dranandsp@gmail. com

\begin{abstract}
Medicinal plant plays a key role for ailment of various chronic diseases due to the presence of phytochemical constituent. The preliminary phytochemical compounds were studied using the ethanol, ethyl acetate, diethyl ether, chloroform, and aqueous extracts of 15 wild edible fruits collected from Boda and Kolli hills. The phytochemical compounds such as phenol, tannins, saponin, alkaloid, flavonoids, steroids, phlobotannins, terpenoids, anthraquinones and cardiac glycosides were screened in 15 edible fruits using standard methods. The diethyl ether extract, ethyl acetate, and ethanol extract of the selected fruits shows the presence of phytochemicals compound. The highest occurrence shows the high therapeutic value possessing majority of a phytochemical constituent of active compounds. In further studies, the compound from these fruits was isolated and used for medicinal purposes.
\end{abstract}

KEY WORDS: Phytochemical compounds, therapeutic efficacy, wild edible fruits

\section{INTRODUCTION}

Herbal medicines are traditionally used about $80 \%$ of the world population primarily in developing country like India, for the primary health care (Kamboj, 2000). The traditional medicines plants help us a great promise as an easily available and low cost-effective medicinal agents to cure a wide range of ailments among the people particularly in a tropical area. The people consume several plant or plant derived formulations to cure various diseases and disinfection. Phytochemicals compounds are naturally occurring in medicinal plants parts such as leaves, stem bark, fruits, and roots. These compounds have the ability of defense mechanism against various diseases causing agents such as microbes and virus. Natural products from plants called secondary metabolites are the end products of primary metabolites such as carbohydrates, amino acid, chlorophyll, lipids and so on. They are synthesis large variety of chemical substances known as secondary metabolites which include alkaloids, steroids, flavonoids, terpenoids, glycoside, saponin, tannins, and phenolic compounds (Doss, 2009). The secondary metabolites are very good antioxidant compounds. The richness of phytochemical bioactive compound posses antioxidant, antitumor, anti-inflammatory, anti-atherosclerotic, antimutagenic, anticarcinogenic, antibacterial, antiviral, and antiparasitic activities (Rice-Evans et al., 1995; Ashok Kumar et al., 2008). In recent years, many investigations were progressed with unknown pharmacological activities for the source of therapeutic agents. The aim of this study was to evaluate the phytochemical compounds from aqueous, ethanol, diethyl ether, chloroform, and ethyl acetate extracts of 15 edible fruits.

\section{MATERIALS AND METHODS}

\section{Phytochemical Screening Analysis of Secondary Metabolites}

Phytochemical tests were carried out using various extract such as aqueous, ethanol, diethyl ether, chloroform, and ethyl acetate to identify various constitutes using standard methods of Trease and Evans, 1997 and Sofowra, 1993. The phytochemical tests in a brief account were conducted as following:

1. Phenol: The extract $(0.5 \mathrm{~g})$ was dissolved in $5 \mathrm{ml}$ of distilled water. To this, add few drops of neutral (5\%) ferric chloride solution. A dark green color indicated the presence of phenolic compounds.

2. Tannin: The one gram of fruit extract added with $100 \mathrm{ml}$ of distilled water, boiled them, makes them to cool and filtered it. Add 1\% ferric chloride drop by 
drop to the filtrate. Green black precipitate shows the presence of tannin.

3. Saponins: About $2 \mathrm{ml}$ of sodium bicarbonate (1\%) was added to $1 \mathrm{ml}$ of extract and shake it well. Lather like formation remains constant for some time is indicative of the presence of saponin.

4. Alkaloids: Crushed and filtered $1 \mathrm{ml}$ of fruits extract was taken in a test tube. Then, add $2 \mathrm{ml}$ of aqueous hydrochloric acid (1\%). Heat it for few minutes. Furthermore, add 2-3 drops of dragendroff reagent in the solution. Reddish brown precipitate color appeared with turbidity depicts shows alkaloid presence.

5. Flavonoids: To the $5 \mathrm{ml}$ of extract was taken, add $1 \mathrm{ml}$ of sodium hydroxide solution (10\%). Add two drops of concentrated hydrochloric acid in the side of the beaker. The yellow color changes to colorless which shows the presence of flavonoids.

6. Phlobatannins: The extract was added with $1 \mathrm{ml}$ of aqueous hydrochloric acid (1\%) followed by boiling. A red precipitate is indicates the presence of phlobatannins.

7. Steroids: $100 \mu \mathrm{l}$ fresh extract was taken in a test tube and add $400 \mu \mathrm{l}$ of acetic anhydride. Then, add 1 or 2 drops of concentrated sulfuric acid. Brown ring at the boundary of mixture shows the presence of steroids.

8. Terpenoids: $2 \mathrm{ml}$ of the organic extract was taken. Then dissolved in $2 \mathrm{ml}$ of chloroform and let them evaporated to dryness. Add $2 \mathrm{ml}$ of concentrated sulfuric acid and heated for about $2 \mathrm{~min}$. Development of a grayish color indicates the presence of terpenoids.

9. Anthraquinone: $1 \mathrm{ml}$ of extract was taken. Add $2 \mathrm{ml}$ of potassium hydroxide (5\%). Filter it. A color change into pink was observed. These show the presence of anthraquinone.

10.Cardiac glycosides: $100 \mu \mathrm{l}$ of extract was taken in a test tube and add $400 \mu \mathrm{l}$ of acetic anhydride. Then, add 1-2 drops of concentrated sulfuric acid. The presence of glycosides shows by the appearance of blue-green color.

\section{RESULTS AND DISCUSSION}

Phytochemical analyzed on the selected 15 fruits extracts shows the presence of bioactive compound which is known to reveal medicinal properties as well as physiological activities (Sofowra, 1993). Screening of the plant extracts is to find out the presence of phytochemicals such as phenols, tannins, flavonoids, saponins, glycosides, steroids, terpenoids, and alkaloids. 10 phytochemical tests were showed the positive and negative in all extract of the 15 fruits extracts showed in Tables 1 and 2. The plant such as Coccinia indica, Carissa carandas, Carissa spinarum, Ficus benghalensis, Ficus religiosa, Hugnoia mystax, Limonia acidissima, Morinda pubescens, Murraya koenigii, Phoenix loureiroi, Pithecellobium dulce, Phyllanthus emblica, Syzygium cumini, Ziziphus mauritiana, and Ziziphus oenoplia is taken for phytochemical screening. Some of these plants may have the presence of secondary metabolites such as phenol, tannins, flavonoids, alkaloids, saponins, phlobatannins, steroids, terpenoids, anthraquinones, and cardiac glycosides.

Phenol is one of the omnipresent groups of plant metabolites (Singh et al., 2007). In this analysis, most of the selected edible fruits extracts have the presence of phenolic compound except the C.spinarum and L. acidissima. The presence of phenol had pharmacological properties such as anti-apoptosis, anticarcinogen, anti-inflammation, anti-aging, anti-atherosclerosis, inhibition of angiogenesis, cell proliferation activities, and cardiovascular protection (Han et al., 2007). C. carandas, C. spinarum, and L. acidissima show the presence of tannins. Tannins involve in protein synthesis. It is a large polyphenolic group of secondary compound. It contains sufficient hydroxyls groups and other suitable groups to form a strong complex with other macromolecules. The presence of tannin used as astringents against diarrhea (Yoshida et al., 1991), as diuretics (Hatano et al., 1991; Okuda et al., 1983), duodenal tumors (Saijo et al., 1989), anti-inflammatory, antiseptic, and hemostatic pharmaceuticals (Haslam, 1996). H. mystax, Z. mauritiana, and $Z$. oenoplia shows the presence of saponin in all solvent extracts. The presence of saponin is used to stop hemorrhage and for healing the wounds and ulcers, also it helps in red blood cell coagulation (Okwu and Josiah, 2006). Saponins helps as an anti-inflammatory (Just et al., 1998), precipitating and coagulating red blood cells, cholesterol binding properties, hemolytic activity, and bitterness (Okwu, 2004; Sodipo et al., 2000), and antibacterial properties (Epand et al., 2007). The H. mystax, $L$. acidissima, $M$. pubescens, $M$. koenigii, P. loureiroi, and P. dulce show the presence of alkaloids compounds. The alkaloids group shows the chemical compounds which contain basic nitrogen atoms. It produced by a large variety of organisms including bacteria, fungi, plants, and animals (Luch, 2009). It has importance medicinal properties is their cytotoxicity (Nobori et al., 1994), analgesic (Antherden, 1969), antispasmodic (Stray, 1998), and antibacterial (Stray, 1998). Flavonoids group helps in plant metabolites to provide cell signaling pathways and antioxidant activity. All fruits extract shows the presence of flavonoids compounds. Flavonoids are the important antibiotics group. These antibiotic principles are effective in defensive mechanism of the plants against different microbes (Hafiza, 2000). The presences of flavonoids are 
Table 1: Phytoscreening analysis of secondary metabolites

\begin{tabular}{|c|c|c|c|c|c|c|c|c|c|c|c|c|c|c|c|c|c|c|c|c|c|c|c|c|c|}
\hline \multirow[t]{2}{*}{ Botanical name } & \multicolumn{5}{|c|}{ Phenol } & \multicolumn{5}{|c|}{ Tannin } & \multicolumn{5}{|c|}{ Saponin } & \multicolumn{5}{|c|}{ Alkaloids } & \multicolumn{5}{|c|}{ Flavonoids } \\
\hline & $\mathrm{EA}$ & $E$ & $A$ & DEE & C & EA & $\mathrm{E}$ & $A$ & DEE & C & EA & $\mathrm{E}$ & W & DEE & C & EA & $\mathrm{E}$ & $A$ & DEE & C & $\mathrm{EA}$ & $\mathrm{E}$ & $A$ & DEE & C \\
\hline Coccinia indica & + & + & + & + & + & + & + & + & + & + & + & + & - & + & - & + & + & - & + & - & + & + & + & + & + \\
\hline Carissa carandas & + & + & + & + & - & + & + & - & - & - & + & + & + & + & + & + & + & - & - & - & + & + & + & + & + \\
\hline Carissa spinarum & + & + & - & + & + & + & + & - & - & - & + & + & - & + & - & + & + & - & - & - & + & + & + & + & + \\
\hline Ficus benghalensis & + & + & + & + & + & + & + & + & + & + & - & + & - & - & - & + & + & - & - & - & + & + & + & + & + \\
\hline Ficus religiosa & + & + & + & + & + & + & + & + & + & + & - & + & - & - & - & - & - & - & - & - & + & + & + & + & + \\
\hline Hugnoia mystax & + & + & + & + & + & + & + & + & + & + & + & + & + & + & + & + & + & - & - & - & + & + & + & + & + \\
\hline Limonia acidissima & + & + & - & + & + & + & + & - & - & - & + & + & + & + & + & + & + & + & + & + & + & + & + & + & + \\
\hline Morinda pubescens & + & + & + & + & + & + & + & + & + & + & - & + & - & - & - & + & + & + & + & + & + & + & + & + & + \\
\hline Murraya koenigii & + & + & + & + & + & + & + & + & + & + & - & + & - & - & - & + & + & + & + & + & + & + & + & + & + \\
\hline Phoenix loureiroi & + & + & + & + & + & + & + & + & + & + & + & + & + & + & + & + & + & + & + & + & + & - & + & + & + \\
\hline Pithecellobium dulce & + & + & + & + & + & + & + & + & + & + & - & + & - & - & - & + & + & + & + & + & + & + & + & + & + \\
\hline Phyllanthus emblica & + & + & + & + & + & + & + & + & + & + & + & + & - & + & - & + & + & - & - & - & + & + & + & + & + \\
\hline Syzygium cumini & + & + & + & + & + & + & + & + & + & + & - & + & - & - & - & + & + & + & + & + & + & + & + & + & + \\
\hline Ziziphus mauritiana & + & + & + & + & + & + & + & + & + & + & + & + & + & + & + & + & + & + & + & + & + & + & + & + & + \\
\hline Ziziphus oenoplia & + & + & + & + & + & + & + & + & + & + & + & + & + & + & + & + & + & - & - & - & + & + & + & + & + \\
\hline
\end{tabular}

EA: Ethyl acetate, E: Ethanol, A: Aqueous; DEE: Diethyl ether, C: Chloroform

Table 2: Preliminary Phytoscreening analysis of secondary metabolites

\begin{tabular}{|c|c|c|c|c|c|c|c|c|c|c|c|c|c|c|c|c|c|c|c|c|c|c|c|c|c|}
\hline \multirow[t]{2}{*}{ Botanical name } & \multicolumn{5}{|c|}{ Phlobatannins } & \multicolumn{5}{|c|}{ Steroids } & \multicolumn{5}{|c|}{ Terpenoids } & \multicolumn{5}{|c|}{ Anthraquinones } & \multicolumn{5}{|c|}{ Cardiac glycosides } \\
\hline & EA & $E$ & A & DEE & C & EA & $E$ & $\mathrm{~A}$ & DEE & C & EA & $E$ & A & DEE & C & EA & $E$ & A & DEE & C & EA & $E$ & $A$ & DEE & C \\
\hline & + & + & - & + & + & - & + & & - & - & + & + & + & 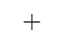 & + & & & & + & + & & & & + & + \\
\hline & . & - & + & - & - & + & + & + & + & + & + & + & - & - & . & - & - & & - & & + & + & + & & - \\
\hline & - & + & - & - & - & - & + & - & + & + & . & - & - & . & - & - & - & & - & & + & + & + & & - \\
\hline lensis & + & + & - & + & + & + & + & + & + & + & + & + & - & - & - & - & - & & - & & & + & + & + & + \\
\hline & - & + & + & - & - & + & + & + & + & + & + & + & + & + & + & + & + & & + & + & + & + & - & & - \\
\hline & + & + & - & + & + & + & + & + & - & + & + & + & + & + & + & + & - & - & + & + & & + & + & + & + \\
\hline Lin & - & - & - & - & - & - & - & + & + & + & + & + & + & + & + & - & + & + & + & + & + & + & - & & - \\
\hline escens & - & + & - & - & - & + & + & - & + & + & - & - & - & - & - & + & - & + & - & - & + & + & - & & - \\
\hline & - & - & - & - & - & + & + & + & + & + & + & + & + & + & + & + & + & + & + & + & + & + & + & & - \\
\hline reiroi & - & + & - & - & - & + & + & + & + & + & - & + & - & - & - & + & + & + & - & - & + & + & + & & - \\
\hline ium dulce & - & - & - & - & - & - & - & + & - & + & + & + & + & + & + & + & + & + & + & + & + & - & + & - & - \\
\hline emblica & + & + & + & + & + & + & + & + & + & + & - & + & - & - & - & + & + & + & - & - & + & + & + & + & + \\
\hline Syzygium cumini & - & + & - & - & - & + & + & + & + & + & + & + & - & - & - & + & + & - & - & - & + & + & + & - & - \\
\hline uritiana & + & + & + & + & + & + & + & + & + & + & + & + & + & + & + & - & + & + & + & + & + & + & + & + & + \\
\hline Ziziphus oenoplia & + & + & + & + & + & + & + & + & + & + & + & + & + & + & + & + & + & - & + & + & + & + & + & + & + \\
\hline
\end{tabular}

EA: Ethyl acetate, E: Ethanol, A: Aqueous; DEE: Diethyl ether, C: Chloroform

used as pharmacological activity such as antimicrobial activity (Cowan, 1996), antioxidant (Salah et al., 1995), and anticancer activities (Del-Rio et al., 1997; Okwu, 2004). C. indica, H. mystax, P. emblica, Z. mauritiana, and $Z$. oenoplia shows the presence of phlobatannins. The phlobatannins are secondary metabolites belongs to phenolic compounds. The presence of phlobatannins has a medicinal properties of antioxidant (Kumari and Jain, 2015), anti-inflammatory (Okwu and Okwu, 2004), wound healing and analgesic activities (Ayinde et al., 2007). C. carandas, F. benghalensis, F. religiosa, M. koenigii, P. loureiroi, P. emblica, S. cumini, Z. mauritiana, and Z. oenoplia shows the presence of steroids. Steroids are cholesterol derived lipophilic group it is important secondary metabolites. The presence of steroids used in antihormones (Jovanovic et al., 2015), contraceptive drugs (Lopez et al., 2006), anticancer agents (Thao et al., 2015), cardiovascular agents (Rattanasopa et al., 2015), osteoporosis drugs (Hoppé et al., 2011), antibiotics, anesthetics, anti-inflammatory, and antiasthmatics (Aav et al., 2005). M. koenigii, P. loureiroi, F. religiosa, H. mystax, P. emblica, S. cumini, Z. mauritiana, and $Z$. oenoplia shows the presence of terpenoids. Terpenoids are secondary metabolites; it has molecular structures that containing carbon as backbones with isoprene units. Isoprene contains five carbon atoms. As a result, the number of carbon atoms is a multiple of five in any terpenoids. The terpenoids consist of two isoprene units, i.e., 10 carbon atoms. The classification of terpenoids based on the number of isoprene units (Ashour et al., 2010). The presence of terpenoids shows significant pharmacological activities, such as antiviral, antibacterial, antimalarial, anti-inflammatory, inhibition of cholesterol synthesis, and anticancer activities (Mahato and Sen, 1997). L. acidissima, P. dulce, Z. mauritiana, and Z. oenoplia shows the presence of anthraquinone. An anthraquinone are the secondary metabolites. The presence of anthraquinones has the 
medicinal properties of antibacterial, antitrypanosomal, and anti-neoplastic activities (Heyman et al., 2009; Tarus et al., 2002; Velez and Osheroff, 2004).

F. benghalensis, H. mystax, P. emblica, Z. mauritiana, and $Z$. oenoplia shows the presence of cardiac glycosides. Cardiac glycosides are the secondary metabolites which help to reduce the blood pressure (Nyarko and Addy, 1990). It has organic compounds containing glycosides (sugar) that act on the contractile force of the cardiac muscle. The presence of cardiac glycosides is used as medicines for treating heart failure and certain irregular heartbeats. Cardiac glycosides are used to lower the blood pressure (Nyarko and Addy, 1990).

The results obtained in the presence study suggest that the identified phytochemical compounds perhaps bioactive constituents and these plants prove an increasingly valuable bioactive compound for significant medicinal worth.

\section{CONCLUSION}

The results obtained in this study shown the presence of medicinally important bioactive compound in the selected 15 fruits extract of plants. Many evidences were proved in advance studies which confirmed the identified phytochemicals to be bioactive compounds. Finally, it has been concluded that the presence of various phytochemical compounds in the selected edible fruit extracts has the major bioactive constituents. These bioactive compounds are having a valuable reservoir for the therapeutic merit. Therefore, the selected plant fruits extracts could be a good source for useful drugs.

\section{ACKNOWLEDGMENT}

Authors are grateful to the DST-SERB for giving financial supports under the Major Research Project for young scientists (F. No. SB/YS/LS-364/2013) and thankful to the management and administrative authorities of National College (Autonomous) for their encouragement and support.

\section{REFERENCES}

Aav R, Kanger T, Pehk T, Lopp M. Unexpected reactivity of ethyl 2-(Diethylphosphono) propionate toward 2,2-disubstituted-,3-cyclopentanediones. Phosphorus Sulfur Silicon Relat Elem 2005;180:1739-48.

Antherden LM. Textbook of Pharmaceutical Chemistry. $8^{\text {th }} \mathrm{ed}$. London: Oxford University Press; 1969. p. 813-4.

Ashok Kumar D, Mazumder UK, Gupta M, Senthil Kumar GP, Selvan VT. Evaluation of antioxidant and free radical scavenging activities of Oxystelma esculentum in various in vitro models. J Complement Integr Med 2008;5:1-6.

Ashour M, Wink M, Gershenzon JG. Biochemistry of terpenoids: Monoterpenes, sesquiterpenes and diterpenes. In: Wink M, editor. Biochemistry of Plant Secondary Metabolism.Vol. 40. New Jersey: JohnWiley \& Sons; 2010.

Ayinde BA, Omogbai EK, Amaechina FC. Pharmacognosy and hypotensive evaluation of Ficus exasperata Vahl (Moraceae) leaf. Acta Pol Pharm 2007;64:543-6.

Cowan MM. Plant products as antimicrobial agents. Clin Microbiol Rev 1999;12:564-82.

Del-Rio A, Obdululio BG, Casfillo J, Main FG, Ortuno A. Uses and properties of Citrus flavonoids. J Agric Food Chem 1997;45:4505-15.

Doss A. Preliminary phytochemical screening of some Indian medicinal plants. Anc Sci Life 2009;29:12-6.

Epand RF, Savage PB, Epand RM. Bacterial lipid composition and the antimicrobial efficacy of cationic steroid compounds (Ceragenins). Biochim Biophys Acta 2007;1768:2500-9.

Hafiza RE. Peptide antibiotics. Lancet 2000;349:418-22.

Han X, Shen T, Lou H. Dietry polyphenols and their biological significance. Int J Mol Sci 2007;8:950-88.

Haslam E. Natural polyphenols (vegetable tannins) as drugs: Possible modes of action. J Nat Prod 1996;59:205-15.

Hatano T, Yazaki K, Okonogi O, Okuda T. Tannins of Stachyurus species II: Praecoxins A, B, C and D, four new hydrolysable tannins for Stachyurus species tree. Chem Pharm Bull 1991;39:1689-93.

Heyman HM, Hussein AA, Meyer JJ, Lall N. Antibacterial activity of South African medicinal plants against methicillin resistant Staphylococcus aureus. Pharm Biol 2009;47:67-71.

Hoppé E, Morel G, Biver E, Borg S, Chopin F, Legrand E. Male osteoporosis: Do sex steroids really benefit bone health in men? Joint Bone Spine 2011;78 Suppl 2:S191-6.

Jovanovic-Šanta SS, Petri ET, Klisuric OR, Szécsi M, Kovacevic R, Petrovic JA. Antihormonal potential of selected D-homo and D-seco estratriene derivatives. Steroids 2015;97:45-53.

Just MJ, Recio MC, Giner RM, Cueller MU, Manez S, Billia AR, et al. Anti-inflammatory activity of unusual lupine saponins from Bupleurum fruticescens 1998;64:404-7.

Kamboj VP. An examination of the importance of plants in tradition ayurvedic system. herbal medicine. Curr Science 2000; 78:35-9.

Kumari M, Jain S. Screening of potential sources of tannin and its therapeutic application. Int J Nutr Food Sci 2015;4:26-9.

Lopez LM, Grimes DA, Shulz KF, Curtis KM. Steroidal contraceptives: effect on bone fractures in women. Cochrane Database of Syst Rev 2006;2:7.

Luch A. Molecular, Clinical and Environmental Toxicology. Berlin: Springer; 2009. p. 20.

Mahato SB, Sen S. Advances in triterpenoid research, 1990- 
1994. Phytochemistry 1997;44:1185-236.

Nobori T, Miura K, Wu DJ, Lois A, Takabayashi K, Carson DA. Deletions of the cyclin-dependent kinase-4 inhibitor gene in multiple human cancers. Nature 1994;368:753-6.

Nyarko AA, Addy ME. Effects of aqueous extract of Adenia cissampeloides on blood pressure and serum analyte of hypertensive patients. Phytother Res 1990;4:25-8.

Okuda T, Hatano T, Yazaki K, Guavin B. An ellagitannin a novel type. Chem Pharm Bull 1983;31:333.

Okwu DE, Josiah C. Evaluation of the chemical composition of two Nigerian medicinal plants. Afr J Biotech 2006;5:357-61.

Okwu DE, Okwu ME. Chemical composition of Spondias mombin Linn plant parts. J Sustain Agric Environ 2004;6:140-7.

Okwu DE. Phytochemicals and vitamin content of indigenous species of southeastern Nigeria. J Sustain Agric Environ 2004;6:30-7.

Rattanasopa C, Phungphong S, Wattanapermpool J, Bupha-Intr T. Significant role of estrogen in maintaining cardiac mitochondrial functions. J Steroid Biochem Mol Biol 2015;147:1-9.

Rice-Evans CA, Miller NJ, Bolwell PG, Bramley PM, Pridham JB. The relative antioxidant activities of plant-derived polyphenolic flavonoids. Free Radic Res 1995;22:375-83.

Saijo R, Nonaka G, Nishioka I. Tannins and related compounds. LXXXIV. Isolation and characterization of five new hydrolyzable tannins from the bark of Mallotus japonicus. Chem Pharm Bull (Tokyo) 1989;37:2063-70.

Salah N, Miller NJ, Paganga G, Tijburg L, Bolwell GP, Rice-Evans C. Polyphenolic flavanols as scavengers of aqueous phase radicals and as chain-breaking antioxidants. Arch Biochem Biophys 1995;322:339-46.

Singh R, Singh S, Kumar S, Arora S. Evaluation of antioxidant potential of ethyl acetate extract/fractions of Acacia auriculiformis A. Cunn. Food Chem Toxicol 2007;45:1216-23.

Sodipo OA, Akiniyi JA, Ogunbamosu JU. Studies on certain characteristics of extracts of bark of Pansinystalia macruceras (K schemp) picrre exbeille. Glob J Pure Appl Sci 2000;6:83-7.

Sofowra A. Medicinal Plants andTraditional Medicine in Africa. Ibadan, Nigeria: Spectrum Books Ltd.; 1993. p. 191-289.

Stray F. The Natural Guide to Medicinal Herbs and Plants. London: Tiger Books International; 1998. p. 12-6.

Tarus PK, Machocho AK, Lang'at-Thoruwa CC, Chhabra SC. Flavonoids from Tephrosia aequilata. Phytochemistry 2002;60:375-9.

Thao NP, Luyen BT, Kim EJ, Kang JI, Kang HK, Cuong NX, et al. Steroidal constituents from the edible sea urchin Diadema savignyi Michelin induce apoptosis in human cancer cells. J Med Food 2015;18:45-53.

Trease GE, Evans WC. Pharmacognosy. XIV ${ }^{\text {th }}$ ed. London: Mac Millian Publishing Ltd.; 1997. p. 568-78.

Velez CR, Osheroff N. DNA topoisomerases: Type II. In: Encyclopedia of Biological Chemistry. San Diego: Elsevier Inc.; 2004. p. 806-11.

Yoshida T, Ohbayashi H, Ishihara K, Ohwashi W, Haba K, Okano Y, et al. Tannins and related polyphenols of Melastomataceous plants. I. Hydrolyzable tannins from Tibouchina semidecandra COGN. Chem Pharm Bull 1991;39:2233-40. 